\title{
高純度金属スズ中の酸化スズ(IV) の定量
}

\author{
松 本 健 ${ }^{\circledR}$ ，輿石 秀美，寺田喜久雄* \\ (1983 年 11 月 21 日受理)
}

\begin{abstract}
$100 \mathrm{ml}$ 分液漏斗に $14 \%$ 塩化銅 $(\mathrm{II})$ カリウム溶液 $50 \mathrm{ml}$ を入れ, 窒素を通じ脱酸素してから, 試 料の高純度金属スズ片を加えて振り混ぜると，金属スズは溶解し，酸化スズ(IV) は不溶残留物とな る. 酸化スズ(IV) を沪別した後，ヨウ化アンモニウム融解法によって迅速，簡便に分解する. 昇華分 離したヨウ化スズ(IV) を捕集し，0.5 M 塩酸で溶解した溶液中のスズ量を黒鉛炉原子吸光法で定量し て酸化スズ(IV) 量を求める. 本法はイォン化傾向の差を利用した置換溶解法であり，選択溶解性は良 好であった．数百 $\mathrm{mg}$ の試料を用い，微量の酸化スズ(IV) を短時間に高い精度で正確に定量できる.
\end{abstract}

\section{1 緒言}

金属スズ中の酸化スズ(IV) を分離, 定量するための 分析化学的研究は極めて少なく, 二, 三の報告があるに すぎない，例えば，Ruf ${ }^{1)}$ は酸化スズ(IV) 中の金属ス ズ及び酸化スズ(II) を塩素酸カリウムと塩酸によって 溶解し, その総スズ量を抽出吸光光度法で定量した.こ の方法は抽出の繰り返しと有機相の洗浄の繰り返し操作 を必要とする. Spauszus ら²)は硫酸鉄 (III) 一硫酸溶液を 用いる置換溶解法によって酸化スズ(IV) 中の金属スズ を定量した. 彼らは, 二酸化炭素気流下でかき混ぜなが ら 3 時間加熱するか, 耐圧容器中で 3 時間振り混ぜて金 属スズを溶解している. 束原ら ${ }^{3)}$ は銅-スズ合金中の酸 化スズ(IV) を臭素-メタノール法及び酸分解法で定量 する際の最適条件を検討した. 酸化スズ(IV) の回収率 は 95 97\% 程度であり, 試料の分解に長時間を必要と しから酸化スズ(IV) の分解とスズの定量操作は大変に 煩雑である. いずれの方法も操作は煩雑で長時間を必要 とするなど多くの共通した問題があり，いまだ満足する 定量法が確立されていないのが現状である.

著者らは各種の高純度金属中の母金属酸化物の定量に ついて報告4～10）を行ってきたが，今回はその一連の研 究として高純度金属スズ中の酸化スズ(IV) の定量を試

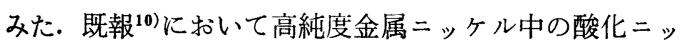
ケル (II) の塩化銅 $(\mathrm{II})$ カリウム溶液を用いる置換溶解法 による定量法を報告した. 本研究はこれに引き続き塩化 銅(II) カリウム溶液を用いる置換溶解法による定量法に

* 金沢大学理学部化学科：920 石川県金沢市丸の内 1-1
ついて検討した.すなわち，金属スズはイオン化傾向の 差により式 (1) に従って選択的に置換溶解するが, 酸化 スズ(IV) は全く溶解せずに残留物となることを知り得 たので，高純度金属スズ試料を脱酸素した $14 \%$ 塩化銅

$$
\begin{aligned}
& \mathrm{Sn}+\mathrm{CuCl}_{2} \longrightarrow \mathrm{SnCl}_{2}+\mathrm{Cu} \\
& \mathrm{Cu}+\mathrm{CuCl}_{2} \longrightarrow 2 \mathrm{GuCl} \ldots \ldots
\end{aligned}
$$

(II) カリウム溶液で処理した後, 不溶残留物となる酸 化スズ(IV) を沪別した。 酸化スズ(IV) の分解は, こ れまで分解容器の損傷による污染や操作が煩雑などの問 題がある水酸化ナトリウムあるいは過酸化ナトリウム融 解法に頼らざるを得なかったが，本研究では著者らが先 に確立したヨウ化アンモニウム融解法 ${ }^{11)}$ を適用するこ とにより，酸化スズ(IV) を迅速，簡便に分解し，黒鉛 炉原子吸光法を用いて高い精度と再現性をもって定量で きたのでここに報告する。

\section{2 試薬と装置}

\section{$2 \cdot 1$ 試 薬}

金属スズ：片山化学工業製粉末金属スズ (試薬一級), Alfa Division Ventron 社製板状金属スズ（99\%以上表 示，厚さ $0.33 \mathrm{~mm}$ ), 同社製切削片状金属スズ (99.997 $\%$ 表示）及び 同社製針金状金属スズ（99.999％表示， 径 $0.5 \mathrm{~mm}$ ) を用いた.

スズ標準溶液：金属スズ $(99.999 \%) 1 \mathrm{~g}$ を精ひょう し, 濃塩酸 $20 \mathrm{ml}$ に加熱溶解後, $2 \mathrm{M}$ 塩酸を加えて 1 1 に定量とし， Sn $1 \mathrm{mg} / \mathrm{ml}$ の溶液を得た。この溶液を ストック溶液とし，使用の都度適当に希䣋して用いた。

酸化スズ (IV)：金属スズ (99.999％) を用い，文献 $\left.{ }^{12}\right)$ に従って調製したものを用いた。得られた酸化スズ (IV) について X 線回折図を求めたが，ASTM カード 
記載のものと一致し, 又蛍光X線分析では不純物は検出 できなかった。

$14 \%$ 塩化銅 $(\mathrm{II})$ カリウム溶液：試薬特級塩化銅 $(\mathrm{II})$ カリウム $140 \mathrm{~g}$ を水に溶解し, 試薬特級酒石酸 $4 \mathrm{~g}$ を加 えて溶解した後, 水を加えて 11 とした. 使用に際して 窒素を通じ酸素を除いたものを用いた。

ヨウ化アンモニウム：試薬特級品を用いた.

酸化スズ(IV)-石英粉末希釈試料：既報11)の少法に往 って調製した。得られた希䣋試料の組成は $\mathrm{SnO}_{2} 0.5$ $\mathrm{mg} / \mathrm{g}$ 石英であり, 光学顕微鏡観察と化学分析によりそ の均質性を確かめて用いた。

窒素: 市販の窒素ボンべ（純度 $99.9 \%$ 以上）から得 られるものを, 既報9）の方法に従って酸素を除いて用い た.

水は純水を用い，その他の試薬は特級品を用いた。

\section{$2 \cdot 2$ 装}

原子吸光装置：日立製 170-50 型原子吸光計に同社製 GA-2 型グラフォイトアトマイザーを取り付け，原子吸 光シグナルは同社製 056-1001 型記録計に記録した. 浜 松テレビ社製中空陰極ランブ (Sn: $224.6 \mathrm{~nm})$, 原子化 時のバックグラウンド補正には同社製高輝度重水素ラン ブを用いた。試料の注入には Eppendorf 社製マイクロ ピペッ $(10 \mu \mathrm{l})$ を用いた。 又，別に島津製 AA-646 型原子吸光計に空気ーフセチレンフレームを用いた.

$\mathrm{X}$ 線回折装置: 理学電機製 Geiger Flex

エネルギー分散型蛍光 $\mathrm{X}$ 線装置: Edax 社製 $920 \mathrm{D}$

ガスメーター：品川製作所製 WK-1 型湿式ガスメー ター

沪過装置：小型のガラスフィルター（G4）を共すり とした漏斗足と組み合わせて用いた．Fig. 1 に概略を示

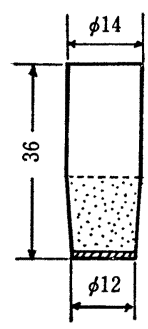

(a)
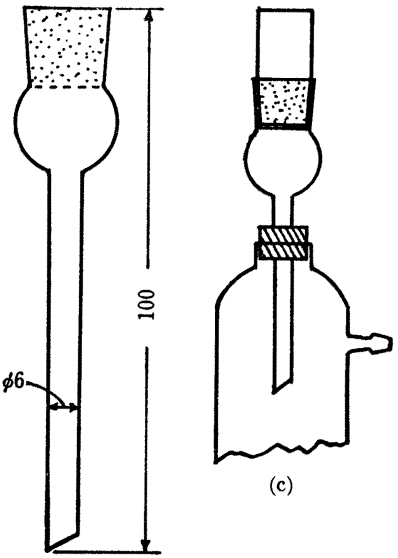

(c) (b)

Fig. 1 Apparatus for filtration

(a) Sintered glass filter (G4), with ground glass joint; (b) Adapter, (c) Assembled form; Figures are expressed in $\mathrm{mm}$.
す.ガラスフィルターの大きさは融解容器の反応管中に 入るように作製した.

融解容器：酸化スズ(IV)を分解するための既報11) の 装置を Fig. 2 のように改良して用いた。なお，加熱温 度は約 $350^{\circ} \mathrm{C}$ 程度であり，ガラスフィルター-(G4) は繰り返し用いることができた。

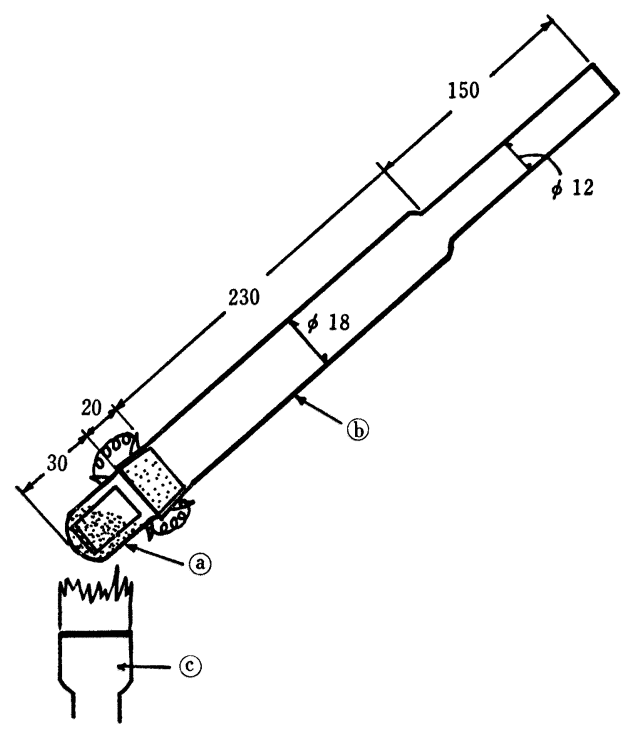

Fig. 2 Apparatus for decomposition of tin(IV) oxide

(a): Decomposition tube (sintered glass filter with $\mathrm{SnO}_{2}$, ammonium iodide and platinum); (b): Cold trap tube; (C): Fish-tail burner

\section{3 定量操作}

$100 \mathrm{ml}$ 分液漏斗に $14 \%$ 塩化銅 $(\mathrm{II})$ カリウム溶液 $50 \mathrm{ml}$ を採り, 窒素を $0.71 / \mathrm{min}$ の流速で 10 分間通 じて脱酸素した後，精ひょらした試料金属を投入し，窒 素䨌冊気中で 30 分間振り混ぜる. 分液漏斗のコックを 開いて溶液を抜き出し，ガラスフィルター（G4）を通 して吸引沪過すると, 不溶残留物の酸化スズ(IV) はフ ィルター上に捕集される. 分液漏斗及びガラスフィルタ 一を $14 \%$ 塩化銅(II)カリウム溶液で十分洗浄した後, 水で十分に洗浄し，更にガラスフィルターを精製エタ， ールで洗浄して乾燥する. 沪別した酸化スズ(IV) をガ ラスフィルターごと融解容器の反応管中に入れ, これに ヨウ化アンモニウム $2 \mathrm{~g}$ 亡白金線の小片を加える. 冷却 管を取り付け，冷却管の上部を手で持ち，回しながら魚 尾形ガスバーナーの上で反応管と冷却管の接続部分を加 熱した後, 反応管の底部を静かに加熱する ${ }^{11)}$. 直ちに反 応生成物のヨウ化スズ(IV) が昇華して冷却管の内壁に 
付着するが，ヨウ化アンモニウムがすべて昇華するまで 加熱する. 反応は約 1 分間で終了する. 冷却後, 冷却管 を取り外し，内壁に付着した昇華物を $0.5 \mathrm{M}$ 塩酸で溶 解し, メスフラスコに移し入れ, $0.5 \mathrm{M}$ 塩酸を加えて定 容とする．この溶液中のスズの濃度を黒鉛炉原子吸光法 で定量し, 酸化スズ(IV) 量を求める.

\section{4 実験，結果及び討論}

\section{1 金属スズの塩化銅 $(\mathbf{I I})$ カリウム溶液への溶解}

塩化銅(II)カリウムのみを溶解した水溶液に金属スズ を加えて 振り混ぜると, 金属スズの溶解に従って 金属 表面に淡緑色沈殿物が析出し始め, 金属スズの溶解が大 変遅くなるか完全に溶解しないことを予備実験で知り得 た. 加水分解反応によると考えられるこの現象は既報の 金属ニッケルについても見られ, 酒石酸を添加すること によって解決できた ${ }^{10)}$. そこで, 本研究でも, 酒石酸を 加えた塩化銅(II)カリウム溶液を用いてその効果を調 ベた結果, 酒石酸を $0.4 \%$ 以上の濃度に加えた溶液で は沈殿物の析出は認められなかった. 酒石酸の添加は沈 殿物の生成を防ぐために必すであることが分かった．前 揭 2.1 で示した塩化銅(II)カリウム溶液の 酒石酸濃度 を $0.4 \%$ としたのはこの結果に基づく. 一方, 金属ス ズの溶解速度は塩化銅(II) カリウム溶液の濃度に依存す ることを知り得たので, 以下の実験を行った. すなわ ち, $100 \mathrm{ml}$ 分液漏斗に 5 30\%の塩化銅(II)カリウ 么溶液 $50 \mathrm{ml}$ を採り, 窒素を $0.71 / \mathrm{min}$ の流速で 10 分間通じて脱酸素した後, 金属スズ $(99.999 \%)$ の一定 量を投入し, 栓をして振り混ぜ, 金属スズが完全に溶解 するまでの時間を測定した．栓をする際に分液漏斗内に 空気が混入する場合があるので, 窒素導入管付きプラス チック製キャップを分液漏斗にかぶせて, 活栓の脱着を 行った ${ }^{9)}$. 塩濃度が $10 \%$ 以下の溶液では, 20 分間以 上の振り混ぜを必要とし, ときには完全に溶解しない場 合もあった. 又, $20 \%$ 以上の濃度では, 比較的短時間 (約 10 分間) で金属スズは溶解したが，その後に続く 操作の簡便さを考えて既報 ${ }^{10)}$ と同じ $14 \%$ 塩化銅(II) カリウム溶液を用いることにした。

\section{2 金属スズの溶解に及ぼす 振り混ぜ時間と 溶液の 脱酸素の効果}

金属スズは $14 \%$ 塩化銅(II)カリウム溶液に溶解する ことが分かったので, 完全溶解に 必要な振り混ぜ時間 について定量的に調べた. $100 \mathrm{ml}$ 分液漏斗に $14 \%$ 塩 化銅 (II) カリウム溶液 $50 \mathrm{ml}$ を採り, 窒素を $0.7 \mathrm{l} /$ $\min$ の流速で 10 分間通じて脱酸素した後, 金属スズ
$(99.999 \%)$ の一定量を投入し 所定の時間振り混ぜた. 分液漏斗のコックを開いて溶液を抜き出し，ガラスフィ ルター（G4）を通して吸引沪過した. 沪液の $2 \mathrm{ml}$ を分 取してメスフラスコに移し入れ, $0.5 \mathrm{M}$ 塩酸を加えて定 容とした後, 溶液中のスズの濃度を空気ーアセチレンフ レームを用いた原子吸光法で定量した. Fig. 3 にその 結果を示す. 金属スズは 10 分間の振り混ぜで完全に溶 解することが分かったが，本研究では振り混ぜ時間を 30 分間とした.

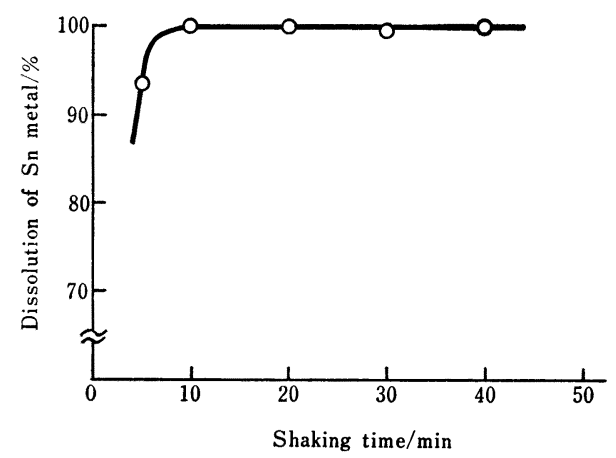

Fig. 3 Effect of shaking time on dissolution of tin metal

Tin metal (wire, purity $99.999 \%$ ) : $200 \mathrm{mg} ; 14 \%$ potassium copper(II) chloride solution : $50 \mathrm{ml}$; Passing time of nitrogen : $10 \mathrm{~min}\left(700 \mathrm{ml} \mathrm{min}^{-1}\right)$

一方, 塩化銅 $(\mathrm{II})$ カリウム溶液の脱酸素が不十分な場 合，振り混ぜ中に残留酸素によって 金属表面が酸化さ れ，多量の酸化スズ(IV) が生成することを予備実験で 知り得た. 本研究の目的からは金属スズが酸化される ことは問題であり，塩化銅(II)カリウム溶液に窒素を通 じて脱酸素しておくことは必要条件であると考えられ る. そこで, 脱酸素の必要時間を求めるために, 金属ス ズ (99.999\%) の一定量を $0.71 / \mathrm{min}$ の流速で 0 18 分間窒素を通じた $14 \%$ 塩化銅 $(\mathrm{II})$ カリウム溶液 $50 \mathrm{ml}$ と 30 分間振り混ぜた. 溶液をガラスフィルター (G4) に通して吸引沪過し，不溶残留物を捕集した。 その後, 3 の操作に従って不溶残留物を分解し, 得られた溶液中 のスズの濃度を定量した. Fig. 4 にその結果を示す. 10 分間以上窒素を通じた溶液については酸化スズ(IV) は一定值となった。この值は用いた金属スズ中の酸化ス ズ(IV) に相当すると考えられ (Table 3), 窒素を 10 分間通じれば脱酸素は十分であることが分かる. 


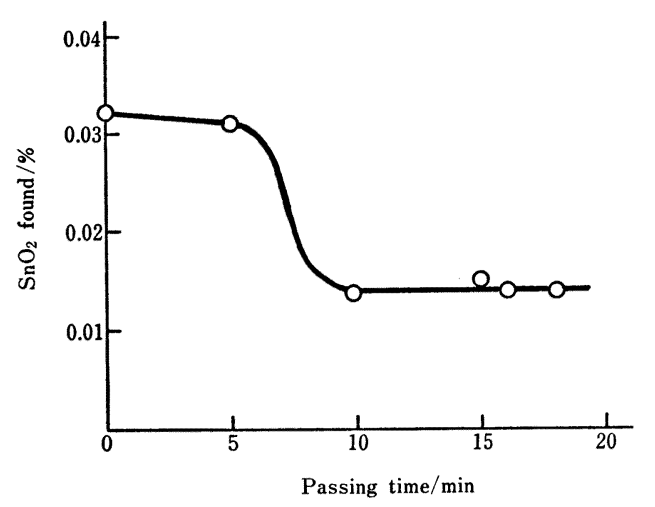

Fig. 4 Effect of passing time of nitrogen on deoxygenation of potassium copper(II) chloride solution

Tin metal (wire, purity $99.999 \%$ ) : $100 \mathrm{mg} ; 14 \%$ potassium copper(II) chloride solution : $50 \mathrm{ml}$; Passing rate of nitrogen : $700 \mathrm{ml} \mathrm{min}^{-1}$; Shaking time $: 30 \mathrm{~min}$

\section{3 酸化スズ $(\mathrm{IV})$ と $14 \%$ 塩化銅 $(\mathrm{II})$ カリゥム溶 液との反応}

窒素を通じて十分に脱酸素した $14 \%$ 塩化銅(II)力 リウム溶液に既知量の酸化スズ $(I V)$ を投入し，窒素雲 囲気とした $100 \mathrm{ml}$ 分液漏斗中で 30 分間振り混ぜ た. 不溶残留物を 3 の操作に従って沪別, 分解した後, 得られた溶液中のスズの濃度を定量した. Table 1 に示 すよらに酸化スズは全く溶解せず，定量的に回収できる ことが分かった。なお，金属スズ中には酸化スズ(IV) 以外に酸化スズ(II) などの存在が考えられ，金属スズ の熱履歴によって無定形, 酸化スズ(II) 及び酸化スズ

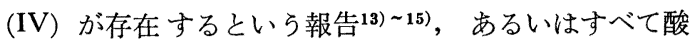
化スズ(IV) であるか酸化スズ(II) が存在しても微量 であるといら報告3) がある，そこで，酸化スズ(II) に ついて上述の操作に従って実験を行った結果, 全く溶解 せず, 定量的に回収された. 従って, 本法では酸化スズ (II) をもすべて酸化スズ(IV) として定量しているとい

Table 1 Recovery of tin(IV) oxide after reaction with $14 \%$ potassium copper(II) chloride solution

\begin{tabular}{ccc}
\hline $\begin{array}{c}\mathrm{SnO}_{2} \text { taken/ } \\
\text { mg }\end{array}$ & $\begin{array}{c}\mathrm{SnO}_{2} \text { found/ } \\
\text { mg }\end{array}$ & $\begin{array}{c}\text { Recovery of } \mathrm{SnO}_{2} / \\
\%\end{array}$ \\
\hline $0.152 \dagger$ & 0.145 & 95.4 \\
$0.190 \dagger$ & 0.192 & 101 \\
4.18 & 4.06 & 97.1 \\
5.08 & 5.18 & 102 \\
6.22 & 6.11 & 98.2 \\
\hline
\end{tabular}

$\dagger$ Synthetic sample, diluted with quartz powder $\left(\mathrm{SnO}_{2} 5.0 \mathrm{mg} / \mathrm{g}\right.$ quartz)
える・

\section{4 金属スズと酸化スズ(IV) の混合物の処理}

$4 \cdot 1 \sim 4.3$ の実験の 結果, 金属スズと酸化スズ(IV) の分離の可能なことが分かったので, 混合物について 3 の操作に従って実験を行った. Table 2 にその結果を示 す. いずれも金属スズは $14 \%$ 塩化銅 $(\mathrm{II})$ カリウム溶 液に完全に溶解し, 酸化スズ(IV) の回収率は良好であ った.

Table 2 Determination of known quantities of tin(IV) oxide added to tin metal

\begin{tabular}{cccc}
\hline $\begin{array}{c}\text { Sn metal takent/ } \\
\text { mg }\end{array}$ & $\begin{array}{c}\mathrm{SnO}_{2} \text { taken/ } \\
\text { mg }\end{array}$ & $\begin{array}{c}\mathrm{SnO}_{2} \text { found/ } \\
\text { mg }\end{array}$ & $\begin{array}{c}\text { Recovery of } \mathrm{SnO}_{2} \text { / } \\
\%\end{array}$ \\
\hline 36.2 & 2.56 & 2.59 & 101 \\
28.4 & 3.24 & 3.44 & 106 \\
47.4 & 5.90 & 5.67 & 96.1 \\
\hline
\end{tabular}

$\dagger$ Purity of tin wire : $99.999 \%$

\section{5 金属スズ中の酸化スズ(IV) の定量}

板状金属スズ (99\% 以上)，粉末金属スズ（試薬一 級), 切削片状金属スズ $(99.99 \%)$ 及び針金状金属スズ $(99.999 \%)$ 中の酸化スズ(IV) を本法により定量した. 結果を Table 3 にまとめて示す.

Table 3 Determination of tin(IV) oxide in tin metal

\begin{tabular}{|c|c|c|c|}
\hline \multirow{2}{*}{ Sn metal (purity/\%) } & \multicolumn{2}{|c|}{$\mathrm{SnO}_{2}$ found } & \\
\hline & $(\mu \mathrm{g})$ & $(\%)$ & \\
\hline \multicolumn{4}{|l|}{ Foil (99) } \\
\hline $\begin{array}{l}196.3 \\
197.4 \\
197.4 \\
200.5\end{array}$ & $\begin{array}{l}62.2 \\
60.9 \\
64.1 \\
60.9\end{array}$ & $\begin{array}{l}0.0317 \\
0.0309 \\
0.0325 \\
0.0304\end{array}$ & $\begin{array}{l}\bar{x}=0.0314 \% \\
\sigma_{n-1}=0.000922 \\
\text { R.S.D. }=2.94 \%\end{array}$ \\
\hline \multicolumn{4}{|l|}{ Powder (E. P.) } \\
\hline $\begin{array}{r}99.7 \\
100.7 \\
103.8 \\
107.5\end{array}$ & $\begin{array}{r}980 \\
1100 \\
940 \\
1130\end{array}$ & $\begin{array}{l}0.983 \\
1.09 \\
0.906 \\
1.05\end{array}$ & $\begin{array}{l}\bar{x}=1.01 \% \\
\sigma_{n-1}=0.0807 \\
\text { R.S.D. }=7.99 \%\end{array}$ \\
\hline \multicolumn{4}{|l|}{ Flinders (99.997) } \\
\hline $\begin{array}{l}201.5 \\
202.2 \\
202.3 \\
202.7\end{array}$ & $\begin{array}{l}42.9 \\
36.2 \\
33.1 \\
53.2\end{array}$ & $\begin{array}{l}0.0213 \\
0.0179 \\
0.0164 \\
0.0262\end{array}$ & $\begin{array}{l}\bar{x}=0.0205 \% \\
\sigma_{n-1}=0.00435 \\
\text { R.S.D. }=21.2 \%\end{array}$ \\
\hline \multicolumn{4}{|l|}{ Wire (99.999) } \\
\hline $\begin{array}{r}99.2 \\
99.4 \\
99.4 \\
100.2\end{array}$ & $\begin{array}{l}13.6 \\
13.6 \\
15.9 \\
12.2\end{array}$ & $\begin{array}{l}0.0137 \\
0.0137 \\
0.0160 \\
0.0122\end{array}$ & $\begin{array}{l}\bar{x}=0.0139 \% \\
\sigma_{n-1}=0.00157 \\
\text { R.S.D. }=11.3 \%\end{array}$ \\
\hline
\end{tabular}

粉末金属スズは比較的純度が低く，その表面積が大き いことから, 酸化スズ(IV) の含有率は $1.01 \%$ と極め て高いものであった. 切削片状金属スズについては，供 試料の表面積の違いから定量值の相対標準偏差は大きく 
なったと考えられる・板状及び針金状金属スズについて

は，定量の精度及び再現性ともに十分であった。

(1983 年 10 月, 日本分析化学 $)$

会第 32 年会において一部発表)

\section{交献}

1) E. Ruf : Freseneius' Z. Anal. Chem., 162, 9 (1958).

2) S. Spauszus, G. Lanz : Chem. Tech. (Berlin), 14, 111 (1962); Chem. Abstr., 57, 1541g (1962).

3) 束原 顸, 山本寿美, 外村高志: 分化, 18, 1229 (1969).

4) 木羽敏泰, 松本 健, 清水源治 : 分化, 24, 116 (1975).

5）松本 健，小泉貞之，木羽敏泰 : 分化， 28，20 (1979).

6) K. Matsumoto, S. Koizumi, T. Kiba : Anal. Chim. Acta, 115, 149 (1980).

7) K. Matsumoto : Anal. Chim. Acta, 123, 297 (1981).

8) K. Matsumoto : Fresenius' Z. Anal. Chem., 305, 370 (1981).

9) 松本 健，木羽敏泰：分化，30，12（1981）。

10) K. Matsumoto, M. Matsuki, K. Terada : Fresenius' Z. Anal. Chem., 309, 398 (1981).

11) 松本 健, 西尾 学, 三崎ゆかり, 寺田喜久雄 : 分化, 31, 141 (1982).

12) 日本化学会編：“新実験化学講座” 8, p. 257 (1976)，(丸善).

13) 島岡五朗, 山井 䉷：日化，76，965 (1955).

14) S. C. Britton, K. Bright : Metallurgia, 56, 163 (1957) ; Chem. Abstr., 52, 220i (1958).

15) S. C. Britton, J. C. Sheslock : Brit. Corros. J., 9, 96 (1974); Chem. Abstr., 81, 85218x (1974).

$$
\text { ş }
$$

Determination of tin(IV) oxide in high purity tin metals. Ken Matsumoto, Hidemi Koshishi, and Kikuo Terada (Department of Chemistry, Faculty of Science, Kanazawa University, 1-1, Marunouchi,
Kanazawa-shi, Ishikawa, 920)

A simple, fast and accurate method for the determination of tin(IV) oxide in high purity tin metals has been developed. A $50 \mathrm{ml}$ of $14 \%(\mathrm{w} / \mathrm{v})$ potassium copper (II) chloride solution containing $0.4 \%(\mathrm{w} / \mathrm{v})$ of tartaric acid was put in a $100 \mathrm{ml}$ separatory funnel, and nitrogen was passed through for $10 \mathrm{~min}$ at a rate of $700 \mathrm{ml}$ $\mathrm{min}^{-1}$ to remove oxygen. In a nitrogen atmosphere a sample of tin metal, usually $200 \sim 300 \mathrm{mg}$ in weight, was added and the funnel was stoppered and immediately shaken vigorously for $30 \mathrm{~min}$ : the metal dissolved in the solution, while the oxide remained as insoluble residue. The tin(IV) oxide was collected quantitatively on a small sintered glass filter (G4) $(3.6 \mathrm{~cm} \times$ $1.4 \mathrm{~cm}$ o.d.) under suction and washed first with potassium copper (II) chloride solution, then with water, and finally with ethanol, and dried. The filter and tin (IV) oxide were placed in a decomposition tube (borosilicate-glass, $5 \mathrm{~cm} \times 1.8 \mathrm{~cm}$ o.d.); $2 \mathrm{~g}$ of ammonium iodide was then added in the same tube, followed by a small piece of platinum wire as catalyst, and the tube was attached to a cold trap (borosilicateglass, $40 \mathrm{~cm} \times 1.8 \mathrm{~cm}$ o.d.). The decomposition tube was gently heated with a fish-tail burner for about $1 \mathrm{~min}$; the sublimate, tin(IV) iodide, was quantitatively collected in the trap. After evolution of iodine had ceased, the tin(IV) iodide was dissolved with $0.5 \mathrm{M}$ hydrochloric acid and the concentration of tin in the resulting solution was determined by graphite furnace atomic absorption spectrometry at the $224.6 \mathrm{~nm}$. This method was applied to commercial high purity tin metal of various forms, and 0.014 to $1.01 \%$ of tin (IV) oxide could be determined with good reproducibility.

(Received November 21, 1983)

\section{Keyword phrases}

determination of tin (IV) oxide in tin metal; selective dissolution of tin metal by potassium copper(II) chloride solution; decomposition of tin(IV) oxide by fusion with ammonium iodide; graphite furnace atomic absorption spectrometry for tin (IV). 